\title{
ROLE OF MILK TRI-IODOTHIRONIN (T3) AND SOME BIOCHEMICAL PARAMETERS ON UDDER STATUS IN DAIRY BUFFALOES
}

\author{
A.M. NABIH and GHADA H.A. EL RAHMAN \\ Animal Reproduction Research institute, Haram Giza. \\ Email: ashraf_nabih27@yahoo.com
}

\section{ABSTRACT}

Received at: 30/12/2014

Transition from pregnancy to lactation in dairy bufallo cows involves considerable metabolic adaptation. Additional stress is incurred during infections such as postpartum mastitis. The effect of naturally acquired bacterial infection of the buffalo udders on the activity of the milk triiodothyronine $\left(\mathrm{T}_{3}\right)$ content, from healthy

Accepted: 15/2/2015 (control) and inflamed quarters, was determined to develop a better understanding of thyroid metabolism in buffalo. The diagnostic procedure included history and clinical examination of the udder, macroscopic evaluation of secretions, the California Mastitis Test (CMT), determination of somatic cell counts, bacteriological examination of milk and some biochemical parameters (AST, ALP, LDH, Malondialdehyde, calcium, phosphorus, sodium and chloride) of the same milk samples. The associations between $\mathrm{T}_{3}$ and other milk constituents were investigated, as well as the relationships between the bacterial species isolated from milk and others biochemical parameters. Bacterial examination, somatic cell counts (SCC) and the percentages of milk constituents were analyzed in 42 buffalo cows suffering from subclinical mastitis in one or more than one udder quarters, as well as from 8 healthy control buffalo cows. In single bacterial isolation, E.coli was the highest isolated bacteria from different scores of SCC (19\%) followed by coagulase negative staphylococcus (CNS) and other streptococci (14.3\% for each) meanwhile the Staphylococcus aureus (S.aureus) was the lowest isolate $(9.5 \%)$. On the other hand, in mixed bacterial infection E.coli with S.aureus and other strept. was the highest categegory $(16.7 \%)$ followed by S.aureus with E.coli $(14.3 \%)$ while CNS with E.coli was the lowest one $(11.9 \%)$.It has been found that milk parameters from inflamed quarters were decreased when compared with controls. The decrease in the milk $\mathrm{T}_{3}$ from subclinical mastitic buffaloe cows was manifested when somatic cell counts were $>5 \times 10^{5} / \mathrm{ml}$ milk. These results suggest that the marked decreased $\mathrm{T}_{3}$ level and different milk contents in mammary secretions during naturally occurring subclinical mastitis is associated with the severity of inflammation. Milk enzymes (AST, ALP and LDH) as well as Malondialdehyde, calcium and phosphorus were detected. Significant elevation of liver enzymes, sodium and chloride were noticed in subclinical mastitis cases than healthy control udder. This study confirms the close inter-relationship between the thyroid hormone $\left(T_{3}\right)$, biochemical parameters and different milk constituents and the severity of bacterial infection causes udder mastitis in addition to bufallo udder health.

Key words: Thyroid hormones, Liver enzymes, Milk electrolytes , Bacterial mastitis and Buffalo cows udder health

\section{INTRODUCTION}

Animal and human milk has been shown to contain not only nutrients but also biologically active molecules such as hormones, growth factors and cytokines. Many of these mammary gland secretory components are enriched in the early phase of lactation and can potentially protect the neonate during the period before the hormone and immune systems are completely developed (Srivastava et al., 1996). Subclinical mastitis is one of the most serious diseases of buffalloe, as the infected animal shows no obvious symptoms and secretes apparently normal milk for a long time, during which causative organisms spread infection in the herd, this represents an important feature of the epidemiology of many forms of bovine mastitis (Bakken and Gudding, 1982). Early diagnosis of mastitis is important for production losses and for enhancing the prospects of recovery. Also, the identification of sub clinically infected gland is urgently required for successful control of mastitis in dairy animals (Ahmed et al., 2008). 
In fact, a significant role of thyroid hormones in the process of intestinal enzymes maturation in new born calves has been documented (S Â LEBODZINÂ SKI et al., 1995). This implies that the final $\mathrm{T}_{3}$ level in milk depends on the rate of $\mathrm{T}_{3}$ degradation and simultaneous generation from $\mathrm{T}_{4}$ within the mammary gland. In naturally acquired bacterial infection of the mammary gland in cows there is a decrease in T3 content in milk, most pronounced in coliform mastitis (S Â LEBODZINÂ SKI et al., 1991) Among others, the presence and the role of thyroid hormones (triiodothyronine), in milk has been considered. It has been found that the quantity of $\mathrm{T}_{3}$ consumed daily in milk, calves may exert a local action in the alimentary tract (S Â LEBODZINÂ SKI et al., 1998). Mastitis, particularly the subclinical type, is one of the most persistent and widely spread disease conditions of importance to milk hygiene and quality among dairy cattle worldwide (Coulon et al., 2002). Mastitis influences the total milk output and modifies milk composition and technological usability.

Mastitis, is one of the most common problems in dairy production, may be clinical, presenting symptoms, or subclinical, with no visible signs. Both clinical and subclinical mastitis cause an increase in milk somatic cell count (SCC), changes in milk composition. Subclinical mastitis is more problematic one, being non-symptomatic, and consequently contribute to decreased milk quantity and quality (Leitner et al., 2008). Subclinical mastitis often occurs in only one udder quarter (Barkema et al., 1997), where by composition and SCC of milk from that udder quarter is affected. When cow composite milk samples are taken, the quarter with a high SCC and lower milk quality is often masked due to the effect of milk from the healthy quarters. (Berglund et al., 2004), which could affect the bulk-tank milk during storage due to enzymatic activity. Milk somatic cells consist mainly of white blood cells, where Polymorphonuclear neutrophil (PMN), and phagocyctes move from bone marrow towards the invading bacteria and are attracted in large numbers by chemical messengers or chemotactic agents from damaged tissues. Masses of PMN may pass between milk producing cells into the lumen of the alveolus, thus increasing the somatic cell count (SCC) as well as damaging secretory cells (Jones and Bailey, 2009). Threshold limits of $3.50 \times 10^{5} \mathrm{SCC} / \mathrm{ml}$ have been fixed for milk quality control and udder health monitoring in the tropics (Ogola et al., 2007), this standard can be used, as an integral component of a control program. The suggested threshold is lower than that used for the acceptance of bulk milk in Europe, New Zealand, and Australia, $4.00 \times 10^{5}$ cells/ml (European Union Council, 1992). The mastitis-causing bacteria broadly classified as contagious or environmental pathogens. Contagious pathogens such as $S$. aureus and $S$. agalactiae can be transmitted from cow to cow, whereas environmental pathogens, such as S. dysgalactiae, S. uberis,
Enterococcus spp., CNS and gram-negative enteric bacilli (Pseudomonas spp., E. coli) can be transmitted during milking from the contaminated environment (Bradley, 2002).

Early identification of udder health problems is essential for dairy farmers and veterinarians to ensure not only udder health but also the milk quality and dairying productivity. Economic aspect may interfere with the routine application of bacteriological examination of quarter milk samples. For this reason, alternative parameters are used to identify trends in the development of the udder health in dairy buffaloes as these parameters indicate inflammation (Park et al., 2007).

One indicator of bacterial infection of the mammary glands is an increase in SCC, which has been used to monitor mastitis in dairy buffaloes (O'Brien et al., 2001). Therefore, SCC has become good management tools for predicting and diagnosing mastitis, (Jonker et al., 2002). Elevated SCC has been associated with a decrease in the percentages of lactose and fat in milk, where the mammary epithelial cells can be damaged by bacteria, resulting in a reduced ability to synthesize milk components. Moreover, urea has been inversely associated with percentages of milk protein and with SCC (Johnson and Young, 2003). Thyroid hormones (TH) belong to a prolactational group of hormones that have lactogenic activity. Like the growth hormones $(\mathrm{GH})$, the TH have the potential to increase milk production markedly (S Â LEBODZINÂ SKI et al., 1991). These biologically active molecules may elicit a variety of local reactions during inflammation and may also protect the neonate against infection during the period before its own immune system is completely developed (Na et al., 1997).

The biochemical changes in milk of both cattle and buffalo are investigated which can be used as diagnostic tool and prognostic markers in mastitic case. SCC and milk components and the most common bacterial species isolated from subclinical mastitis occurred naturally in dairy buffaloes in Egypt were discused. Bovine mastitis not only decrease milk yield, but also alter its composition (Shuster et al., 1991). Changes in milk composition are brought about by impairment of normal synthesis of milk ingredients and also infiltration of some blood constituents into milk as a result of abnormal permeability of blood capillaries in inflamed udder (Rashed et al., 2002). The extent of changes in milk components varied with the severity of mastitis (Metawie and Mohamed 1999). In general it was found that mastitic milk showed alterations in protein, fat, minerals (Yossef et al., 2008).

Study aimed to assessing the relation between $\mathrm{T}_{3}$ milk level and enzymes in milk (GOT, ALP, and LDH) as well as malondialhyde which is one of the 
peroxidation products present in the milk of dairy animals. Also the minerals when present in the secreted milk and their level is affected due to mastitis. Moreover we look to explain the effect of this relation on udder health of dairy buffaloes that may be helpful as mastitic marker for early diagnosis of bacterial mastitis severity.

\section{MATERIAL AND METHODS}

\section{Animals and milk samples:}

The buffaloes (50 in total), came from two separate regions (Animal Reproduction Research institute farm -Haram / Giza and bahteem buffalo farm kaliobia). The diagnosis was made on the basis of history, clinical examination of the udder, macroscopic evaluation of secretions, the Californian Mastitis Test (CMT), determination of somatic cell counts and bacteriological examination of milk. Milk samples were taken aseptically and transported to the laboratory as the following:

Teats were washed thoroughly and dried with a separate towel. Teat ends were cleaned with $70 \%$ Alcohol before sampling. The first three streams of milk from each teat were discarded. Then quantities of 20 to $50 \mathrm{ml}$ of milk were collected aseptically into two sterile vials. Milk samples were transported on ice to the laboratory and kept at $4^{\circ} \mathrm{C}$ until diagnosis of bacteriological assays, analysis of SCC, milk components and biochemical parameters.

42 pooled samples of mammary secretions from subclinically inflamed udders and 8 pooled samples from healthy (control) udders of buffaloes cows were used as material for this study.

\section{California mastitis test (CMT):}

The experimental materials were divided into 4 groups according to the California mastitis test (CMT) results, 0 (showed no agglutination) is negative, $1+$ is weak positive, $2+$ is distinct positive and $3+$ and $4+$ (showed too much clots) are strong positive obtained from the test performed directory, using the method described by Schalm et al. (1971). Milk quarters with a CMT score of 0 or $1+$ were considered healthy, whereas quarters with a CMT score of 2,3 or $4+$ were considered unhealthy.

\section{Somatic cell count (SCC) and milk parameters:}

Somatic cell count was measured automatically using a Bently Soma Count 150 (Bently U.S.A). The percentages of milk components, including milk fat, protein, lactose, urea, total solids (T.S) and solid not fat (SNF) were analyzed by using an infrared milk analyzer (Bentley Instruments Inc.). Somatic cell count values were sorted into 4 categories $<250$ $\mathrm{x} 10^{3}$ cells $/ \mathrm{ml}$ (grade A); 250 to $500 \times 10^{3}$ cells $/ \mathrm{ml}$ (grade B); 500 to $<750 \times 10^{3}$ cells $/ \mathrm{ml}$ (grade C) and $>750 \times 10^{3}$ cells $/ \mathrm{ml}$ (grade D) (Park et al., 2007).

\section{Bacteriological examinations:}

Bacteriological examinations were performed by generally accepted rules according to udder and neonatal diseases department - Animal Reproduction Research institute.

The different species of bacteria were isolated from mastitic milk by traditional ways for isolation and identification. Loopfull of milk sample was streaked onto 5\% sheep blood agar, MacConkey agar, mannitol salt agar and Edward agar plates (Oxoid) then incubated at $37^{\circ} \mathrm{C}$ for $24 \mathrm{~h}$. Colonies were initially assessed by their morphology and hemolysis patterns, followed by Gram staining and motility tests. The isolates were identified according to the procedures of the Quinn et al. (2002). Biochemical tests, specifically, catalase, coagulase, growth on mannitol salt agar, growth in $40 \%$ Ox bile, esculin hydrolysis, sodium hippurate hydrolysis, carbohydrate fermentation tests (glucose, mannitol, ribose, sorbitol, and trehalose), biochemical reaction on MacConkey agar, indole production, Methyl red tests, urease production and citrate utilization tests, Triple sugar iron agar (TSI) were performed as required. In cases where no growth was detected, plates were re-incubated at $37^{\circ} \mathrm{C}$ for an additional $24 h$.

\section{Biochemical examination:}

The milk samples were centrifuged at $3000 \mathrm{rpm}$ for about 5 minutes to remove the fat. Defatted milk samples (whey milk) were used for enzyme assays, they were prepared from the milk according to the technique of Kumar and Mikolajcik (1972). The enzymes activities of AST and ALP were determined according to (Reitman and Frankel 1957), LDH (Cabaud, and Wroblewski, 1958) all these enzymes were determined on a spectrophotometer at wavelengths of 340, 405 and $340 \mathrm{~nm}$, respectively (Babaei et al., 2007). Malondialdehyde concentration in milk was determined according to the modified method of (Suriyasathaporn et al., 2006). The digested and diluted samples were used for the estimation of various macro and micro minerals present in the milk. The levels of sodium and chloride $(\mathrm{mg} / \mathrm{dl})$ in the milk were determined by using the flame photometer Oser (1979). The Calcium and inorganic Phosphorus (mg/dl) were determined by colorimetric method, on spectrophotometer at a wavelength of $720 \mathrm{~nm}$ against standard and blank (Ahmad et al., 2007).

\section{Radioimmunoassay of triiodothyronine:}

Part of each milk sample, after cooling according to the technique of Kumar and Mikolajcik (1972), was stored in aliquost at $-20 \mathrm{c}$ until analysed for triiodothyronine determination according to methods of (S Â LEBODZINÂ SKI et al., 1986; 1998).

\section{Statestical analysis:}

The obtained data were statistically evaluated using ANOVA according to (Snedecor and Cochran, 1989). 


\section{RESULTS}

Table 1: Correlation between somatic cell count (SCC) and California mastitis test (CMT) in the collected pooled milk samples from non-infected and infected buffaloe cows.

\begin{tabular}{|c|c|c|c|c|c|c|c|c|}
\hline \multirow{3}{*}{$\begin{array}{c}\text { Scores of SCC } \\
\times 10^{3} \text { cells } / \mathrm{ml}\end{array}$} & \multirow{2}{*}{\multicolumn{2}{|c|}{$\begin{array}{l}\text { Negative control CMT } \\
\qquad 0 \text { or }+(n=8)\end{array}$}} & \multicolumn{4}{|c|}{ Scores of CMT $(n=42)$} & \multirow{2}{*}{\multicolumn{2}{|c|}{$\begin{array}{l}\text { Total } \\
(n=50)\end{array}$}} \\
\hline & & & \multicolumn{2}{|c|}{$\begin{array}{l}\text { Score }++ \\
(n=16)\end{array}$} & \multicolumn{2}{|c|}{$\begin{array}{l}\text { Score }+++\&++++ \\
(n=26)\end{array}$} & & \\
\hline & No & $\%$ & No & $\%$ & $\mathrm{NO}$ & $\%$ & No & $\%$ \\
\hline$<250 \mathrm{a}$ & 8 & 100 & 0 & 0 & 0 & 0 & 8 & 16 \\
\hline $250-<500 b$ & 0 & 0 & 11 & 68.8 & 5 & 19.2 & 16 & 32 \\
\hline $500-<1000 c$ & 0 & 0 & 4 & 25.0 & 10 & 38.5 & 14 & 28 \\
\hline$>1000 d$ & 0 & 0 & 1 & 6.2 & 11 & 42.3 & 12 & 24 \\
\hline
\end{tabular}

Table 2: Correlation between somatic cell count (SCC) and other milk parameters in infected and non-infected buffaloe cows.

\begin{tabular}{lcccccccccccccccc}
\hline \multirow{2}{*}{ Animal case } & \multicolumn{2}{c}{ SCC } & \multicolumn{2}{c}{ Fat $\%$} & Protein $\%$ & Lactose $\%$ & Urea mg/dl & & T.S\% & S.N.F\% \\
\cline { 2 - 13 } & Mean & SE & Mean & SE & Mean & SE & Mean & SE & Mean & SE & Mean & SE & Mean & SE \\
\hline Non-infected & 166 & 6 & 6.80 & 0.07 & 3.40 & 0.04 & 5.57 & 0.03 & 23.1 & 0.19 & 15.8 & 0.1 & 9.60 & 0.05 \\
\hline Single infection & 715 & 9 & 4.00 & 0.12 & 3.56 & 0.06 & 4.67 & 0.06 & 24.6 & 0.29 & 15.5 & 0.11 & 8.70 & 0.08 \\
\hline Mixed infection & $>1000$ & 13 & 3.87 & 0.07 & 3.65 & 0.11 & 4.55 & 0.09 & 25.2 & 0.29 & 14.9 & 0.16 & 8.59 & 0.09 \\
\hline
\end{tabular}

T.S: total solid.

S.N.F: solid not fat.

Table 3: prevalence of isolated bacteria in relation to somatic cell count (SCC) in infected buffaloe cows.

\begin{tabular}{|c|c|c|c|c|c|c|c|c|}
\hline \multirow{3}{*}{ Isolated bacteria } & \multicolumn{6}{|c|}{ Scores of SCC $\times 10^{3}$ cells $/ \mathrm{ml}$} & \multicolumn{2}{|c|}{ Total } \\
\hline & \multicolumn{2}{|c|}{$\begin{array}{c}250-<500 b \\
(n=16)\end{array}$} & \multicolumn{2}{|c|}{$\begin{array}{c}500-<1000 c \\
(n=13)\end{array}$} & \multicolumn{2}{|c|}{$\begin{array}{l}>1000 d \\
(n=13)\end{array}$} & \multirow[b]{2}{*}{ No } & \multirow[b]{2}{*}{$\%$} \\
\hline & No & $\%$ & No & $\%$ & No & $\%$ & & \\
\hline S.aureus & 2 & 12.5 & 1 & 7.6 & 1 & 7.7 & 4 & 9.5 \\
\hline CNS & 3 & 18.7 & 2 & 15.4 & 1 & 7.6 & 6 & 14.3 \\
\hline E.coli & 3 & 18.7 & 2 & 15.4 & 3 & 23.1 & 8 & 19.0 \\
\hline Other strept. & 4 & 25.0 & 0 & 0 & 2 & 15.4 & 6 & 14.3 \\
\hline S.aureus + E.coli & 1 & 6.3 & 2 & 15.4 & 3 & 23.1 & 6 & 14.3 \\
\hline $\mathrm{CNS}+$ E.coli & 2 & 12.5 & 3 & 23.1 & 0 & 0 & 5 & 11.9 \\
\hline S.aureus+ E.coli+ Other strept. & 1 & 6.3 & 3 & 23.1 & 3 & 23.1 & 7 & 16.7 \\
\hline Total & 16 & 100 & 13 & 100 & 86 & 100 & 42 & 100 \\
\hline
\end{tabular}


Table 4: Levels of Tri-iodo thironin ( $\mathrm{T}$ 3) and liver enzymes in whey milk samples from non-infected and infected buffaloe cows.

\begin{tabular}{cccc}
\hline Parameters & $\begin{array}{c}\text { Negative control } \\
\text { (Noninfectedanimals) } \\
(\mathrm{n}=8)\end{array}$ & \multicolumn{2}{c}{$\begin{array}{c}\text { Infected animals } \\
(\mathrm{n}=42)\end{array}$} \\
\hline & Control & $\begin{array}{c}\text { Single infection } \\
(\mathrm{n}=24)\end{array}$ & $\begin{array}{c}\text { Mixed infection } \\
(\mathrm{n}=18)\end{array}$ \\
\hline T3(ng/ml) & $7.70 \pm 0.41^{\mathrm{a}}$ & $5.22 \pm 0.65^{\mathrm{b}}$ & $3.54 \pm 0.51^{\mathrm{c}}$ \\
\hline GOT(AST) $(\mathrm{iu} / \mathrm{L})$ & $21.30 \pm 2.60^{\mathrm{a}}$ & $32.01 \pm 2.26^{\mathrm{b}}$ & $48.20 \pm 3.1^{\mathrm{c}}$ \\
\hline $\mathrm{ALP}(\mathrm{iu} / \mathrm{L})$ & $279.60 \pm 28.11^{\mathrm{a}}$ & $420.07 \pm 40.55^{\mathrm{b}}$ & $566.25 \pm 60.38^{\mathrm{c}}$ \\
\hline LDH $(\mathrm{iu} / \mathrm{L})$ & $81.15 \pm 7.91^{\mathrm{a}}$ & $174.38 \pm 21.32^{\mathrm{b}}$ & $186.42 \pm 20.21^{\mathrm{c}}$ \\
\hline $\begin{array}{c}\mathrm{c} \\
\text { Malondialdehyde } \\
(\mathrm{nmol} / \mathrm{ml})\end{array}$ & $17.3 \pm 2.90^{\mathrm{a}}$ & $31.30 \pm 4.28^{\mathrm{b}}$ & $50.11 \pm 5.1 \mathrm{nmol} / \mathrm{ml}^{\mathrm{c}}$ \\
\hline
\end{tabular}

Means with different superscripts $(a, b, c)$ within arrow are significantly different at $P<0.05$

Table 5: Major elements in whey milk samples from non-infected and infected buffaloe cows.

\begin{tabular}{lccc}
\hline \multicolumn{1}{c}{ Parameters } & $\begin{array}{c}\text { Negative control } \\
\text { (Noninfectedanimals } \\
(\mathrm{n}=8)\end{array}$ & \multicolumn{2}{c}{$\begin{array}{c}\text { Infected animals } \\
(\mathrm{n}=42)\end{array}$} \\
\hline $\begin{array}{l}\text { Calcium } \\
(\mathrm{mg} / \mathrm{dl})\end{array}$ & $95.24 \pm 1.33^{\mathrm{a}}$ & $\begin{array}{c}\text { Singl infection } \\
(\mathrm{n}=24)\end{array}$ & $\begin{array}{c}\text { Mixed infection } \\
(\mathrm{n}=18)\end{array}$ \\
\hline $\begin{array}{l}\text { Phosphorus } \\
(\mathrm{mg} / \mathrm{dl})\end{array}$ & $45.32 \pm 1.89^{\mathrm{b}}$ & $75.81 \pm 2.11^{\mathrm{c}}$ \\
\hline $\begin{array}{l}\text { Sodium } \\
(\mathrm{mmol} / \mathrm{l})\end{array}$ & $48.45 \pm 1.18^{\mathrm{a}}$ & $39.54 \pm 1.07^{\mathrm{b}}$ & $30.90 \pm 1.06^{\mathrm{c}}$ \\
\hline $\begin{array}{l}\text { Chloride } \\
(\mathrm{mmol} / \mathrm{l})\end{array}$ & $36.18 \pm 1.38^{\mathrm{a}}$ & $45.16 \pm 1.22^{\mathrm{b}}$ & $66.26 \pm 1.55^{\mathrm{c}}$ \\
\hline
\end{tabular}

Means with different superscripts $(\mathrm{a}, \mathrm{b}, \mathrm{c})$ within arrow are significantly different at $\mathrm{P}<0.05$.

\section{DISCUSSION}

In cows, the somatic cell count (SCC) is a useful predictor of subclinical mastitis, and therefore, it is an important component of milk in terms of quality, hygiene, and mastitis control.

In this concern Pyörälä (2003) recorded that using CMT as indicator of inflammation to detect mastitis found to be suitable for herd monitoring programmes. CMT has an advantage of being very inexpensive and the only cow-side test with real-time results for selection of the quarters for subsequent bacteriological examination (Sandholm, 1995). Interestingly, it has been observed that in cow composite milk samples with SCC, 100000 cells $/ \mathrm{ml}$, more than $10 \%$ included individual udder quarters with a CMT score $>3.50 \%$ of these quarters were infected with bacteria (Berglund et al., 2004). It has recently been indicated that there are systemic effects on all quarters when one quarter is affected by an increased SCC (Merle et al., 2007).

From Table (2) it noticed increase in SCC and all milk parameters decreased (Fat, Lactose, T.S and S.N.F) except Protein and urea which nearly not changed by increasing SCC. Mean Fat\% decreased from 6.8 to $4.00 \%$ and 3.87 as SCC increased from 166 to 715 and $>1000 \times 10^{3}$ cells $/ \mathrm{ml}$ in non infected, single infected udder and mixed infected udder respectively. Mean Lactose\% decreased from 5.57 to $4.67 \%$ and 4.55 in non infected, single infected udder and mixed infected udder respectively. Mean T.S\% decreased from 15.8 to 15.1 and 14.9 in non infected, single infected udder and mixed infected udder respectively. Mean S.N.F \% decreased from 9.60 to 8.70 and 8.59 in non infected, Single infected udder and mixed infected udder respectively While Protein $\%$ and urea \% nearly not affected with differences in SCC. The obtained results agreed with that of (Berglund et al., 2007 and Gomaa and Mosallam 2014) who reported that, when udders with elevated SCC were compared to healthy udders, milk composition was found to be different With decreasing bulk milk SCC, fat and lactose contents increased, with little effect on protein content. Furthermore, Fernandes et al. (2004) investigated the relationship between SCC and composition (total solids, fat, protein and lactose content) of milk from individual Holstein cows and indicated that SCC of individual cow's milk significantly correlated with a decrease in milk constituents only under conditions of 
average SCC in bulked milk above 1,000,000 cells/ml. Moreover, urea has been inversely associated with percentages of milk protein and with SCC (Johnson and Young, 2003). As the SCC grade increased, lactose percentage. In contrast, the percentages of milk fat and protein increased between grades 2, but decreased between grades 3 and 5 (Ma et al., 2000 and Park et al., 2007).

SCC was significantly changed from 166 to 715 and above 1000 in cases 0f non-infected to single infected and mixed infected udders respectively .Meanwhile there were no significant difference between single or mixed infection in different milk constituents.

As shown in Table (3) E.coli (environmental bacteria) is the highest isolated bacteria from different scores of SCC either single (19\%) or mixed with other bacteria (with S.aureus and other strept.; $16.7 \%$, with S.aureus only; 14.3 while the lowest mixed infection of E.coli was with CNS ; $11.9 \%$ ). These result are nearly similar with that recorded by Haltia et al. (2006). Other strept.bacteria and CNS bacteria were isolated as, environmental bacteria also, in equal percentage, $14.3 \%$. On the other hand contagious bacteria (S.aureus) was recorded as the lowest percentage $9.5 \%$ which disagree with study of Aasmäe et al. (2000).

The results in Table (3) revealed that in cases of single bacterial subclinical mastitis, E.coli elevated the mean SCC in three grades B, C and D (18.7\%, $15.4 \%$, and $23.1 \%$, respectively with mean of $19 \%$ ) followed by other strept. (25\%, $0 \%$ and $15.4 \%$, respectively with mean of $14.3 \%$ ), which was equal with the mean of CNS wih differential of $(18.7 \%$, $15.4 \%$ and $7.6 \%$ respectively) ended by $S$. aureus $(12.5 \%, 7.6 \%$ and $7.7 \%$, respectively with mean of $9.5 \%)$.These results are in agreement with Oliver et al. (2005) who reported that environmental bacteria were significant cause of subclinical mastitis and elevated SCC in the infected udder. Additionally the majority of pathogens in the obtained results were E.coli, which disagreed with Berglund et al. (2004), and SAFAA et al. (2010) as will as this variation may be attributed to bad hyagine and fair management in the farms under study. On the other hand in cases of mixed bacterial infection, the group infected with E.coli with S.aureus and other strept. was the highest mean percentage; $16.7 \%(6.3 \%, 23.1 \%$ and 23.1 respectively) followed by E.coli and S.aureus with mean of $14.3 \%(6.3 \%, 15.4 \%$ and $23.1 \%$ respectively) while the lowest mixed isolates was for E.coli and CNS with mean of $11.9 \%(12.5 \%, 23.1 \%$ and $5 \%$ respectively).

Estimating of triiodothyronine levels in the present investigation indicated that subclinical mastitic buffalo cows with single and mixed infection had significant decrease of whey triiodothyronine levels as compared with non mastitic buffalo cows $(\mathrm{p}<0.05)$.
Decreased milk $\mathrm{T}_{3}$ concentration not be manifested unless the S.C.C in milk is high enough (more than 500.000 cells) or milk shows macroscopic changes. The milk samples classified as CMT scored +++ and ++++ (Inflamed) showed a low $\mathrm{T}_{3}$ concentration paralleled by markedly decreased in 5monodeiodinase activity when compared with milk from healthy control udders from the same buffalo cows (S $\hat{A}$ LEBODZINÂ SKI et al., 1986). In naturally acquired bacterial infection of the mammary gland in cows there is a decrease in $\mathrm{T}_{3}$ content in milk, most pronounced in coliform mastitis ( $\mathrm{S} \hat{\mathrm{A}}$ lebodzin $\hat{A}$ ski et al., 1991). The whole milk and the cellular components, namely macrophages, lymphocytes and granulocytes, have been found to be able to degrade iodothyronines, which may account for the lowered $\mathrm{T}_{3}$ levels in milk from the cows displaying infectious mastitis (S Â LEBODZINÂ SKI et al., 1991). The activity of 5-thyroxine deiodinase (5 -MD) appears to be a normal enzymatic component of cow and pig milk, and one of its possible roles is to generate $T_{3}$ locally, from $T_{4}$, to meet the metabolic demands of the mammary gland tissue for the hormone (S Â LEBODZINÂ SKI et al., 1999).

As shown in the present study after reaching a certain level of severity of inflammation, the milk from infected udders displayed a significant decrease in $\mathrm{T}_{3}$ concentration coincided. Enzymatic activity AST, ALP, LDH and malondialdehyde values as in (Table 4) were significantly $(p<0.05)$ higher in subclinical mastitic buffalo cows with single and mixed infection as compared with control group. The origin of LDH in mastitic milk is attributed to leucocytes (Kato et al., 1989) and also epithelial cells from the udder (Zank and Schlatterer, 1998). Bogin and Ziv (1973) have suggested that LDH in milk was a sensitive indicator of epithelial cell damage and subsequently proposed that LDH originated mainly from the damaged udder epithelial cells and from the elevated numbers of leucocytes. In the context of milk lactate being a potential diagnostic measurement for mastitis, In this study the mean activities of LDH was significantly higher in the milk from udders with SCC than in the milk from healthy udders $(p<0.01)$. It seems that the origin of the elevated LDH in mastitic milk is the leucocytes and the parenchyma cells of the udder. Mastitis is associated with changes in physical, chemical, bacteriological and organoleptic properties of milk, besides causing health hazards to the public (Riaz Hussain et al., 2012). The results of the present study showed that the means of AST, ALP \& LDH activities in milks from buffalo cows with subclinical mastitis were significantly $(\mathrm{P}<0.05)$ higher than those from healthy normal buffalo cows. This indicate that using by determination of enzymes activities in serum milk is a sensitive and reliable method for detection of bovine subclinical mastitis. The results are in agreement with results of Batavani 
et al. (2007) who found that the increased in milk enzymes including lactate dehydrogenase, alkaline phosphatase and aspartate aminotransferase and in mastitic animals might be linked with tissue damage occurring in mammary tissue. It is also in agreement with result of Riaz Hussain et al. (2012) who concludes that the enzymes including lactate dehydrogenase, aspartate aminotransferase and alanine aminotransferase were significantly higher in mastitis than healthy buffaloes. Katsoulos et al. (2010) conclude that the determination of $\mathrm{LDH}$ activity in milk whey is a sensitive and reliable method for the detection of subclinical mastitis in dairy buffaloes. The increased levels of various enzymes in milk occur mainly due to increased permeability of microcirculatory vessels in inflamed areas along with leakage from degenerated/necrotic parenchymal cells and leukocytes.

Moreover, the increase in LDH activities were associated to lesser extent with subclinical mastitis. In contrast, the obtained results are disagreement with a study of Yang et al. (2011) who found that milk AST activity was not significantly different between normal and sub clinical infected udders. Lipid peroxidation by free radicals is a key factor in various mammary tissue pathologies including inflamation. Malondialdehyde is one of the peroxidation products present in the milk of dairy animals which can be used to identify the relationship between somatic cell count and udder inflammation (Ibrahim et al., 2011). Electrical conductivity calcuim and inorganic phosphorous data revealed that subclinical mastitc milk showed a significant $(\mathrm{p}<0.05)$ reduction of calcium and inorganic phosphorus levels in whey milk, while sodium and chloride concentrations are significantly ( $\mathrm{p}<0.05$ ) elevated as compared with control group. The increase in electrical conductivity of mastitic milk could be due to higher concentration of salts released due to increased permeability of cell membrane because of inflammatory process and thus might be responsible for increase in $\mathrm{pH}$ of milk samples. However, Roy et al. (2009) reported the result of electrical conductivity of milk samples from mastitic cattle. They also reported an increase in electrical conductivity of milk samples from mastitic animals of both clinically and sub-clinically infected animals. In present study, an increase in the level of sodium in milk samples from mastitic animals was observed, while other minerals including potassium, calcium, and phosphorus decreased. Similar results have previously been reported for cattle (Ahmad et al., 2007 and Batavani et al., 2007). The change in milk $\mathrm{pH}$ is thus related with the increase in sodium levels in the milk and probably the electrical conductivity also is influenced by the change in sodium levels in milk.

\section{CONCLUSION}

Estimation of $\mathrm{T}_{3}$ can be used as mastitis indicator beside SCC. This study confirms the close interrelationship between the thyroid hormone $\left(\mathrm{T}_{3}\right)$, biochemical parameters, milk constituents and the severity of bacterial infection mastitis in addition to bufallo udder health. The decreased $\mathrm{T}_{3}$ content in mammary secretion during naturally occurring subclinical mastitis appeared to be related to alteration in enzymatic activity and lipid peroxidation with severity of inflammation. These parameters can be used as reliable methods for detection and diagnosis of subclinical mastitis in dairy buffaloes. Early diagnosis of subclinical mastitis in dairy animals may be important in reducing production losses and enhancing prospects of recover herds in order to avoid the development of clinical mastitis. The milk electrical conductivity test can also be used for diagnosis of subclinical mastitis.

\section{REFERENCES}

Ahmad T.; Bilal, M.; Uallah, S.; Rahman, ZU. and Muhammad, G. (2007): Impact of mastitis severity on mineral contents of buffalo milk. Pak J Agric Sci, 44: 176-178.

Ahmed, WM.; Sherein, I. and Ghada M. Nabil (2008): Observations on sub-clinical mastitis in buffalo- cows with emphasis on measuring of milk electrical resistance for its early detection. Global Veterinaria 2: 41-4.

Aasmäe, B.; Kalmus, P.; Ö̈̈pik, T. and Klaassen, E. (2000): Mastiidipatogeenide tundlikkus antibiootikumide suhtes. Antimicrobial susceptibility of bovine mastitis pathogens. The Estonian Vet. Rev.1:9-11.

Babaei, H.; Mansouri-Najand, L.; Molaei, MM.; Kheradmand, A. and Sharifan, M. (2007): Assessment of lactate dehydrogenase, alkaline phosphatase and aspartate aminotransferase activities in cow's milk as an indicator of subclinical mastitis. Vet. Res. Commun, 31: 419-425.

Bakken, G. and Gudding, R. (1982): The interdependence between clinical and subclinical mastitis. Acta Agri. Scandin 32: 17.

Barkema, H.W.; Schukken, Y.H.; Lam, T.J.G.M.; Galligan, D.T.; Beiboer, M.L. and Brand, A. (1997): Estimation of interdependence among quarters of the bovine udder with subclinical mastitis and implications for analysis. J. of Dairy Sci. 80, 1592-1599.

Batavani, RA.; Asri, S. and Naebzadeh, H. (2007): The effect of subclinical mastitison milk composition in dairy cows. Iran J. Vet. Res., 8: 205-211.

Berglund, I.; Pettersson, G.O*; Stensson, K. and Svennersten-Sjaunja, K. (2004): Frequency of 
individual udder quarters with elevated CMT scores in cows' milk samples with low somatic cell counts. Vet. Rec. 155, 213.

Berglund, I.; Pettersson, G.O*; Stensson, K. and Svennersten-Sjaunja, K. (2007): Quarter milking for improved detection of increased SCC. Reproduction in Domestic Animals 42: 427-432.

Bogin, E. and Ziv, G. (1973): "Enzymes and minerals in normal and mastitic milk." Cornell Vet., 63: 666-676.

Bradley, A.J. (2002): Bovine mastitis: An evolving disease. Vet. J. 164: 116-128.

Cabaud, P.G. and Wroblewski, F. (1958): Colorimetric measurement of Lactic dehydrogenase activity of body fluids. American Journal of Clinical pathology, 30, 234-236.

Coulon, J.B.; Gasqui, P.; Barnouin, J.; Ollier, A.; Pradel, P. and Pomiès, D. (2002): Effect of mastitis and related-germ on milk yield and composition during naturally-occurring udder infections in dairy cows. Anim. Res. 51: 383-393.

European Union. Council (1992): Laying down the health rules for the production and placing on the market of raw milk, heat-treated milk and milk-based products. Official J. Eur. Comm., 92/46/EEC 16 June L268, 1-32.

Fernandes, A.M.; Oliveira, C.A.F. and Tavolaro, P. (2004): Relationship between somatic cell counts and composition of milk from individual Holstein cows. Arq. Inst. Boil. Sao Paulo. 71: 163-166.

Gomaa, A.M. and Mosallam, T.E. (2014): Relation between Glutathion Peroxidase enzyme and somatic cell count in bovine mastitis. J. Egypt. Vet. Med. Assoc. 74 (4) 645-653.

Haltia, L.; Honkanen-Buzalski, T.; Spiridonova, I.; Olkonen, A. and Myllys, V. (2006): A study of bovine mastitis, milking procedures and management practices on 25 Estonian dairy herds. Acta Veterinaria Scandinavica. 48: 22.

Ibrahim, AM.; AL-Humiany, AA.; Mansour, AMA. and Zaki, HM. (2011): Epidemiology and microbiological studies on mastitis in shecamels. Int. J. Microbiol Res, 2: 18-27.

Johnson, R.G. and Young, A.J. (2003): The association between milk urea nitrogen and DHI Production variables in western commercial dairy herds. J. Dairy Sci. 86: 3008-3015.

Jones, G.M. and Bailey, T.L. (2009): Understanding the Basics of Mastitis. Virginia Cooperative Extension. Publication: 404-233.

Jonker, J.S.; Kohn, R.A. and High, J. (2002): Dairy herd management practices that impact nitrogen utilization efficiency. J. Dairy Sci. 85: 1218-1226.
Kato, K.; Mori, K. and Katon, N. (1989): Contribution of leucocytes to the origin of lactate dehydrogenase isoenzymes in milk of Bovine mastitis. Jpn. J. Vet. Sci., 51: 530-539.

Katsoulos, P.D.; Christodoulopoulos, G.; Minas, A. Karatzia, M.A.; Pourliotis, K. and Kritas, S.K. (2010): The role of lactate dehydrogenase, alkaline phosphatase and aspartate aminotransferase in the diagnosis of subclinical intramammary infections in dairy sheep and goats. J. Dairy Res.77: 107-111.

Kumar, S. and Mikolajcik, E.M. (1972): Electrophoretic immunoelectrophoretic and ultracentrifugal characterization of protein in whey fractions. " J. Dairy Sci., 9: 1237-1242.

Larsen, L.B.; Rasmussen, M.D.; Bjerring, M. and Nielsen, J.H. (2004): Proteases and protein degradation in milk from cows infected with Streptococcus uberis.

Leitner, G.; Silanikove, N.; Jacobi, S.; Weisblit, L.; Bernstein, S. and Merin, U. (2008): The influence of storage on the farm and in dairy silos on milk quality for cheese production. International Dairy J.18, 109-113.

Ma, Y.; Ryan, C.; Barbano, D.M.; Galton, D.M.; Rudan, M.A. and Boor, K.J. (2000): Effects of somatic cell count on quality and shelf-life of pasteurized fluid milk. J. Dairy Sci., 83: 264-274.

Merle, R.; Schröder, A. and Hamann, J. (2007): Cell function in the bovine mammary gland: a preliminary study on interdependence of healthy and infected udder quarters. J. of Dairy Res. 74, 174-179.

Metawie, R.A. and Mohamed, Q.M. (1999): "Some biochemical changes in milk and serum of mastitic Egyptian buffaloes."Zagazig Vet. J., 27 (2): 38-44.

NA, H.R.; Daniels, L.C. and Seeling, L.L.JR (1997): Preliminary study of how alcohol consumption during pregnancy affects immune components in breast milk and blood of postpartum women. Alcohol, 32, 581-589.

O'Brien, B.; Meaney, W.J.; McDonagh, D. and Kelly, A. (2001): Influence of somatic cell count and storage interval on composition and processing characteristics of milk from cows in late lactation. Aust. J. Dairy Technol., 56: 213-218.

Ogola, H.; Shitandi, A. and Nanua, J. (2007): Effect of mastitis on raw milk compositional quality. J. Vet. Sci. 8(3): 237-242.

Oliver, S.P.; Gillespie, B.E.; Headrick, S.J.; Lewis, M.J. and Dowlen, H.H. (2005): Prevalence, rick factors and strategies for controlling mastitis in heifers during the periparturient period. Intl. J. Appl. Res.Vet. Med. 3: 150-162.

Oser, B.L. (1979): "Hawk's physiological chemistry." $14^{\text {th }}$ Ed., pp. 437 440, Graw-Hill Publishing 
Co., Ltd, New York. Improve detection of increased SCC in Quarter milking.

Park, Y.K.; Koo, H.C.; Kim, S.H.; Hwang, S.Y.; Jung, W.K.; Kim, J.M.; Shin, S.; Kim, R.T. and Park, Y.H. (2007): The Analysis of Milk Components and Pathogenic Bacteria Isolated from Bovine Raw Milk in Korea. J. Dairy Sci. 90 (12): 5405-5414.

Pyörälä, S. (2003): Indicators of inflammation in the diagnosis of mastitis. Vet. Res. 34(5): 565-578.

Quinn, P.J.; Markey, B.K.; Carter, M.E.; Donnelly, W.J. and Leonard, F.C. (2002): Veterinary Microbiology and Microbial disease. First Published A Blackwell Science Company.

Rashed, A.M.Y. and Darwish, F.M.M. (2002): "Protective effect of casin and/or ascorbic acid on metabolic and pathological changes induced by malathion insecticide in rats." Vet. Med. J. Giza, 50 (4): 447-473.

Reitman, S. and Frankel, S. (1957): "A colorimetric determination of serum lutamic oxaloacetic and glutamic pyruvic transaminase." Am. J. Clin. Path., 28: 56-58.

Riaz Hussain, Ahrar Khan, M. Tariq Javed and Farzana Rizvi (2012): possible risk factors associated with mastitis in indigenous cattle in Punjab, Pakistan. Pak.Vet. J, 2012, 32(4): 605-608.

Roy, JP.; Tremblay, D Du.; DesCoteaux, L.; Messier, S.; Scholl, D. and Bouchard, E. (2009): Evaluation of the California Mastitis Test as a precalving treatment selection tool for Holstein heifers. Vet Microbiol, 134: 136-142.

Safaa, A. EL-Wakeel; Hanaa, A.E. Asfour and Gomaa, A.M. (2010): The Relationship between Somatic Cell Count, Milk constituents and Pathogenic Bacteria Isolated from Subclinical mastitis in Dairy Cows. J. Egypt. Vet. Med. Assoc. 70 (4) 569-590.

S Â Lebodzinâ Ski, A.B.; Nowak, J.; Gawê̂ Cka, H. and Sechman, A. (1986): Thyroid hormones and insulin in milk; A comparative study. Endocrinologia Experimentalis 20, 247 \pm 255 .

$S \hat{A}$ Lebodzinâ Ski, A.B. and Brzezinâ SkaSâlebodzinâ Ska, E. (1991): Local generation of triiodothyronine by the mammary gland as a source of measurable quantities of the hormone in milk. Endocrine Regulations 25, 83-89.

S Â Lebodzinâ Ski, A.B.; Lipczak, W. and Brzezinâ Ska Sâlebodzinâ Ska, E. (1995): Peroral administration of triiodothyronine (T3) affects absorption of immunoglobulins in calves. Reproduction, Nutrition, Development 35, $387 \pm 393$.

S Â Lebodzinâ Ski, A.B.; Brzezinâ Ska-Sâlebodzinâ Ska, E.; Nowak, J. and Kowalska, K. (1998):
Triiodothyronine (T3), insulin and characteristics of 50-monodeiodinase (5 0 MD) in mare's milk from parturition to 21 days post-partum. Reproduction, Nutrition, Development 38, 235 \pm 244 .

S Â Lebodzinâ Ski, A.B.; Brzezinâ Ska-Sâlebodzinâ Ska, E.; Styczynâ Ska, E. and Szejnoga, M. (1999): Presence of thyroxine deiodinases in mammary gland: possible modulation of the enzymedeiodinating activity by somatotropin. Domestic Animal Endocrinology 17, 161 \pm 169 .

Sandholm, M. (1995): Detection of inflammatory changes in the milk, in: Sandholm, M.; Honkanen-Buzalski, T.; Kaartinen, L.; Pyörälä, S. (Eds.), The bovine udder and mastitis, Gummerus, Jyväskylä, Finland. 89104.

Schalm, O.W.; Carrol, J.E. and Jain, N.C. (1971): Bovine Mastitis, 1st Ed., 132-53. Lea and Febiger, Philadelphia, USA.

Sendecor, G.W. and W.G. Cochran (1989. Iowa s): Statistical methods.7th.ed tate Univ. press. Ames, Iowa.

Shuster, D.E.; Harman, R.J.; Jackson, J. and Hemken, R.W. (1991): "Suppression ofmilk production during endotoxin induced mastitis." J. Dairy Sci., 74: 3763-3774.

Suriyasathaporna, S.; Vnitketkumnuenb, U.; Chewonarinb, T.; Boonyayatraa, S.; Kreausukona, K. and Schukken, YH. (2006): Higher somatic cell counts resulted in higher malondialdehyde concentration in raw cow's milk. Int Dairy J, 16: 1088-1091.

Srivastava, M.D.; Srivastava, A.; Brouhard, B.; Saneto, R., Groh-Wargo, S. and Kubit, J. (1996): Cytokines in human milk. Research for Communication of Molecular Pathology and Pharmacology, 93, 263-287.

Yang, F.Li ; Li, X.S.; He, B.X.; Yang, X.L.; Li, G.H.; Liu, P.; Huang, Q.H.; Pan, X.M. and Li, J. (2011): Malondialdehyde level and some enzymatic activities in subclinical mastitis milk. African Journal of Biotechnology Vol. 10(28), pp. 5534-5538.

Yossef, M.M.; Zommara, M.A.; El-Sherbiney, M.A. and El-Baz, A.M. (2008): "Incidence of subclinical mastitis in buffalo farms in relation to microbial and chemical contents of milk." Proc. Of Middle East and North Africa Conf. for Further Animal Wealth, Cairo International Convention Center, Egypt, 16-18 October.

Zank, W. and Schlatterer, B. (1998): Assessment of subacute mammary inf lammation by soluble biomarkers in comparison to somatic cell counts in quarter milk samples from dairy cows. J. Vet. Med., 45: 41-51. 
$\underline{\text { Assiut Vet. Med. J. Vol. } 61 \text { No. } 144 \text { January } 2015}$

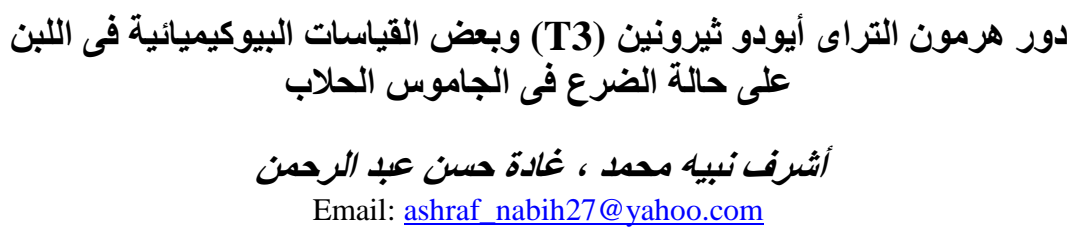

Email: ashraf_nabih27@yahoo.com

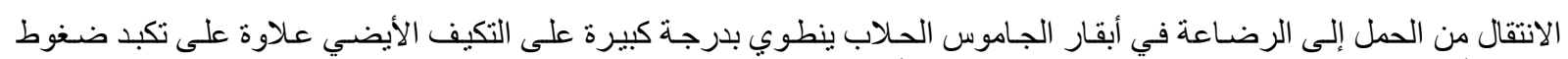

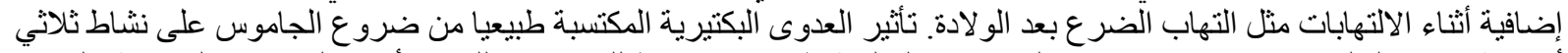

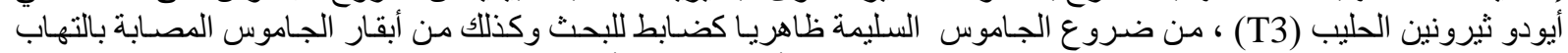

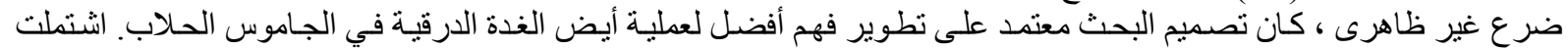

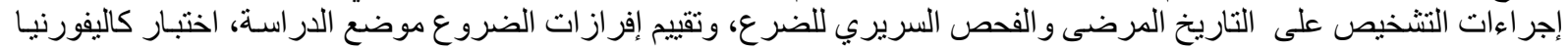

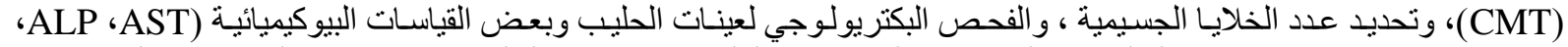

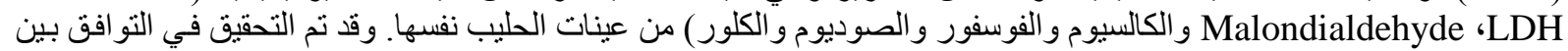

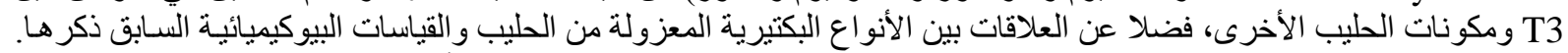

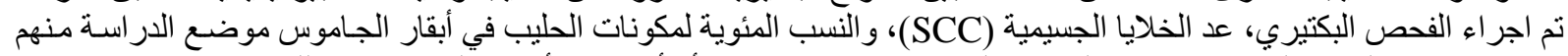

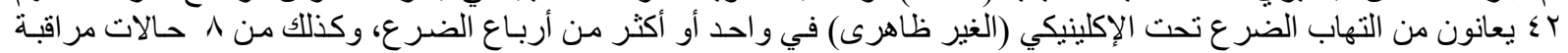

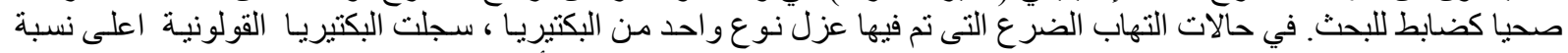

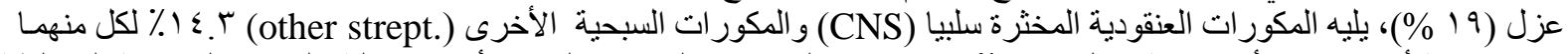

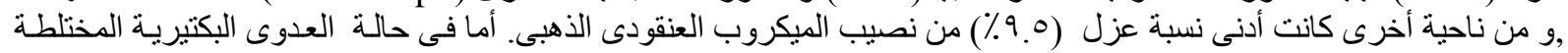

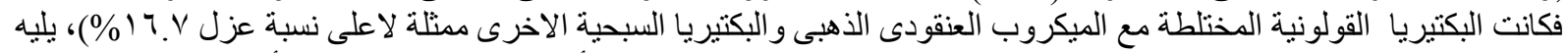

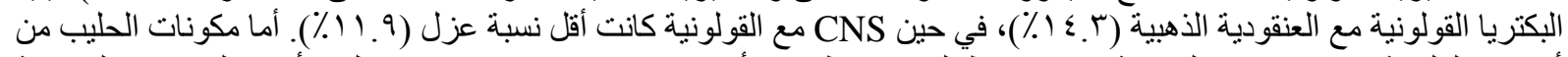

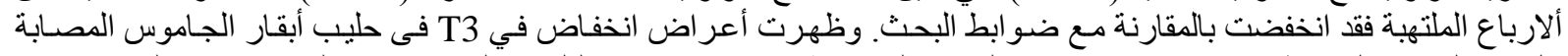

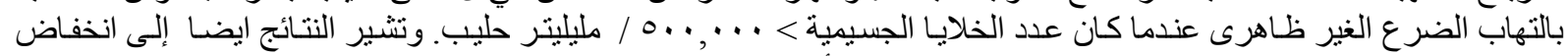

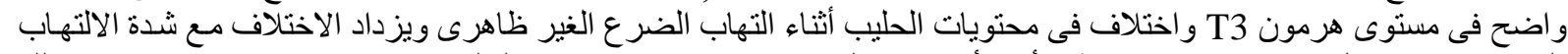

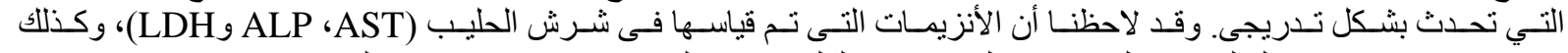

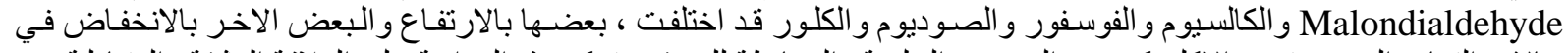

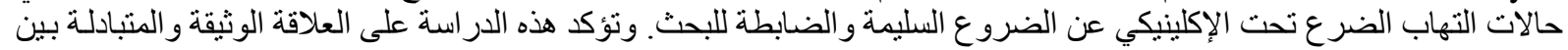

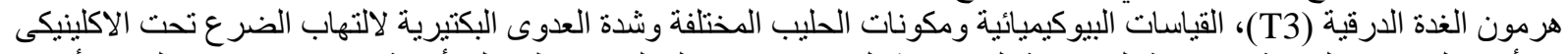

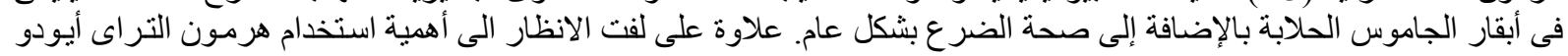
ثيرونين(T3) كدليل من الدلائل التشخيصية لالتهاب الضر الخرع الغير ظاهرى (تحت الاكلينيكى). 